\title{
ASSESSING THE FORECASTING PERFORMANCE OF ARIMA AND ARIMAX MODELS OF RESIDENTIAL PRICES IN ABUJA NIGERIA Musa Abubakar Alkali*
}

Faculty of Built Environment and Survey

University Technology Malaysia

Malaysia

\section{Ibrahim Sipan}

Faculty of Built Environment and Survey

University Technology Malaysia

Malaysia

\section{Muhammad Najib Razali}

Faculty of Built Environment and Survey

University Technology Malaysia

Malaysia

*Corrosponding author's Email: abufatima34@gmail.com

Author's Biography

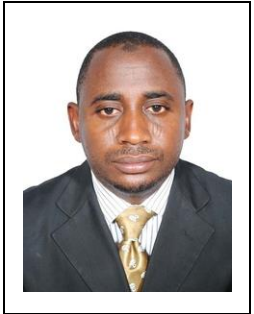

The author was born on 18th September 1978 at Dukku L.G.A Gombe State, Nigeria. He obtained B.Tech Estate Management from Abubakar Tafawa Balewa University Bauchi in 2005, MSc Real estate and Facilities Management at University Tun Hussein on Malaysia in 2015 and PhD Real Estate (in view) at University Technology Malaysia. Presently the author is a lecturer at the Departement of Estate Management, Bayero University Kano, Nigeria.

Peer-review under responsibility of $3^{\text {rd }}$ Asia International Multidisciplanry Conference 2019 editorial board (http://www.utm.my/asia/our-team/) (C) 2019 Published by Readers Insight Publisher, lat 306 Savoy Residencia, Block 3 F11/1,44000 Islamabad. Pakistan, 


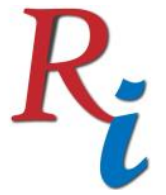

Asia Proceedings of Social Sciences

(APSS)

www.readersinsight.net/APSS

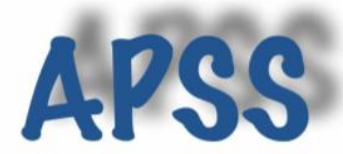

\section{Re se a r ch H i g h I igh t s}

The study assessed the performance of ARIMA and ARIMAX forecasting models of residential price in Abuja Nigeria proposed and results indicated that macroecomic variables such as consumer price index (CPI), crude oil price (COP), Exchange rate (ER), gross domestic product (GDP), household income (HHI) and interest rate (IR) has strong impact on the forecasting models of residential price. Moreover, ARIMAX models provide best out of sample forecasting models than ARIMA.

\section{A b s t r a c t}

This paper compared the out of sample forecasting ability of two Box-Jenkins ARIMA family models: ARIMAX and ARIMA. The forecasting models were tested to forecast real estate residential price in Abuja, Nigeria with quarterly data of average sales of residential price from the first quarter of year 2000 to the last quarter of year 2017. The result shows that the ARIMAX forecasting models, with macroeconomic factors as exogenous variables such as the household income, interest rate, gross domestic products, exchange rate and crude oil price and their lags, provide the best out of sample forecasting models for 2 bedroom, 3 bedroom, 4 bedroom and 5 bedroom, than ARIMA models. Generally, both ARIMA and ARIMAX models are good for short term forecasting modelling.

\section{Research Objectives}

The aim of this paper is to assess the forecasting performance of ARIMA and ARIMAX models of residential prices in Abuja, Nigeria. To achieve the above mentioned aim, the following objective was outlined to determining the impact of macroeconomic variables on residential property price forecasting modelling in the study area. The Forecasting model of real estate price will provide an idea regarding the future trend of the overall macro-economy and thus, can supply important information for designing enhanced and suitable policies. The models will help to provide accurate forecasting which is important to tax assessors, potential homeowners, developers and investors to make investment plans.

\section{Methodology}

This paper used quarterly data of residential property sales in Abuja and macroeconomic variables such as gross domestic product, consumer price index, interest rate, exchange rate of Naira against US dollar, crude oil price and household income. The real estate prices was obtained from the Nigerian Institution of Estate Surveyors and Valuers Bulletin, while the data on macroeconomic variables was obtained from website of Central Bank of Nigeria $(\mathrm{CBN})$. Due to the non-availability of enough real estate data, the sample of study was restricted to only 4 categories of residential property which includes 2 bedroom, 3 bedroom, 4 bedroom and 5 bedroom flats only. The sample period for real estate and macroeconomic variables data was 2000Q1 - 2017Q4. This study used time series forecasting models in accordance with previous studies of Brooks and Tsolacos (2010); (Bork and Møller, 2015) and (Boitan, 2016).

\section{Results}




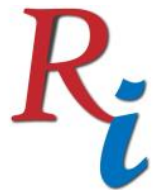

\section{Asia Proceedings of Social Sciences \\ (APSS) \\ www.readersinsight.net/APSS}

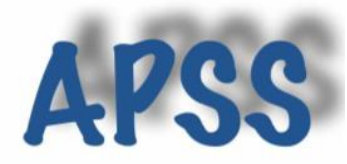

ARIMA model was estimated automatically with Eviews 9.5 by converting all the variables into $\log$ and also done the first time differencing with forecast length 12 . The outcome shows that 25 ARIMA models were estimated and out of 25 models the best models were selected which has the lowest AIC and SBIC values. After selecting the best model, the price of 2,3,4 and 5 bedroom was forecasted, which indicated that, the price is moving gradually with the actual price according to the ARIMA model.

However, ARIMAX model was estimated again by adding consumer price index (CPI), crude oil price (COP), Exchange rate, gross domestic product (GDP), household income (HHI) and interest rate (IR) as exogenous variables. The models revealed that, the price of 2,3,4 and 5 bedroom flats in Abuja will continue to rise. This indicated that macroeconomic variables has strong positive impact on the price of residential properties in Abuja and ARIMAX models provide best out of sample forecasts than ARIMA models. this confirms the findings of Crawford and Fratantoni (2003) and Vishwakarma (2013) that macroeconomic variables has great influence in the future development of property market, because they improve the performance of real estate forecasting..

\section{Findings}

The paper presented the performance of ARIMA and ARIMAX forecasting models presents and revealed that ARIMAX provide the best out-of- sample forecasting models for real estate residential property price in Abuja. Moreover, the result shows that macroeconomic variables has strong impact on the real estate price in Abuja. Moreover, the results shows that macroeconomic variables plays a significant role in developing the real estate price forecasting models. The macroeconomic variables has a strong impact on real estate price forecasting models and this provide a good information to the government and real estate investors as well.

\section{Acknowledgement}

The author greatly acknowledge the School of post graduate studies UTM for the International doctorate fellowship grant as well as federal government of Nigeria for providing financial support to the postgraduate studentship through TETFUND intervention. The usage of used of University Teknologi Malaysia's research facilities are also acknowledged.

\section{References}

Boitan, I. (2016). Residential property prices' modeling: evidence from selected European countries : Journal of European Real Estate Research, Vol. 9(Iss 3), 273-285.

Bork, L., \& Møller, S. V. (2015). Forecasting house prices in the 50 states using Dynamic Model Averaging and Dynamic Model Selection. International Journal of Forecasting, 31(1), 63-78.

Brooks, C., \& Tsolacos, S. (1999). The impact of economic and financial factors on UK property performance. Journal of Property Research, 16(2), 139-152..

Crawford, G. W., \& Fratantoni, M. C. (2003). Assessing the Forecasting Performance of Regime-Switching , ARIMA and GARCH. Real Estate Economics, 31(2), 223-243.

Vishwakarma, V. K. (2013). Forecasting Real Estate Business : Global Journal of Business Research, 7(3), 114. 